\title{
Characterization of Yubileyny Field Ore Potential Based on New Structure-Substance Information
}

\author{
Lyubov Ilyinichna Yalovik*, Alexander Vasilyevich Tatarinov \\ Geological Institute, Siberian Branch, Russian Academy of Sciences, Ulan-Ude, Russia \\ Email: *yalovik_47@mail.ru
}

How to cite this paper: Yalovik, L.I. and Tatarinov, A.V. (2019) Characterization of Yubileyny Field Ore Potential Based on New Structure-Substance Information. Geomaterials, 9, 1-16.

https://doi.org/10.4236/gm.2019.91001

Received: November 13, 2018

Accepted: December 26, 2018

Published: December 29, 2018

Copyright ( 2019 by authors and Scientific Research Publishing Inc. This work is licensed under the Creative Commons Attribution International License (CC BY 4.0).

http://creativecommons.org/licenses/by/4.0/

\section{c) (i) Open Access}

\begin{abstract}
Spatial-genetic relation of a polycomponent ore mineralization (Au, Ag, PGE, $\mathrm{Cu}, \mathrm{Pb}, \mathrm{Zn}, \mathrm{Ni}$ ) with dynamometamorphic complex, formed by the picrite-komatiite-tholeiite series rocks of Kelyana-Irokinda greenstone belt, is identified. Productivity of various ore mineralization morphostructural types (quartz-vein, zones of veining and sulfide dissemination) differing in mineral composition and content of useful components is considered. It is shown that the main industrial value is represented by veined and disseminated ores with relatively poor useful components content, but at the same time forming large-capacity ore zones. The occurrence extent, localization conditions and ore zones hyperthetical resources are favorable for the production of economically cost-effective open pit (quarry) mining operations. An effective sampling method is recommended to carry out the prospect and exploration of large-capacity deposits on the Yubileyny field and other similar to its Transbaikalia ore objects.
\end{abstract}

\section{Keywords}

Ore Mineralization, Quartz Veins, Veined Zones, Dynamometamorphic, Gold, Silver, Platinum Group Elements

\section{Introduction}

Prospecting and exploration works on the area of the Yubileyny ore field were widely carried out by production organizations (Irkutskgeology, "Agrodorspetsstroy" company) in the 60 - 90 years of the last century. Upon these works results, the Yubileyny ore field (Figure 1) was classified as industrial auriferous deposits of medium extent. It is identified that its productivity is determined by 
the hydrothermal quartz-vein mineralization type, characterized by high Au (up to $775 \mathrm{~g} / \mathrm{t}$ ) and $\mathrm{Ag}$ (up to $458.3 \mathrm{~g} / \mathrm{t}$ ) content. A total of 149 quartz veins were discovered. From them with industrial contents, 14 veins opened by mining workings. The studied industrial ore quartz veins parameters are: length 350 $1000 \mathrm{~m}$, capacity $0.1-0.97 \mathrm{~m}$, the content of $\mathrm{Au}-1.6-211 \mathrm{~g} / \mathrm{t}, \mathrm{Ag}-159-641.5$ $\mathrm{g} / \mathrm{t}$. It is identified that the gold bulk (90\%) is in free form, characterizing by consistently high fineness values (880 - 940) [1].

Geological-economic calculations showed that the minimal industrial content of $\mathrm{Au}$ for deposits with veined quartz mineralization is $4 \mathrm{~g} / \mathrm{t}$ [1]. Such type detected bodies with maximum concentrations of $\mathrm{Au}=1.91-3.3 \mathrm{~g} / \mathrm{t}$, turned out to be non-industrial. In the late 90 -ies of the twentieth century, a private company LLC PDSF "Agrodorspetsstroy" carried out a large amount of works (trenches, drilling, underground prospect holes) for further exploration of quartz-vein ore bodies. It was also built an experimental gold extraction factory, which had

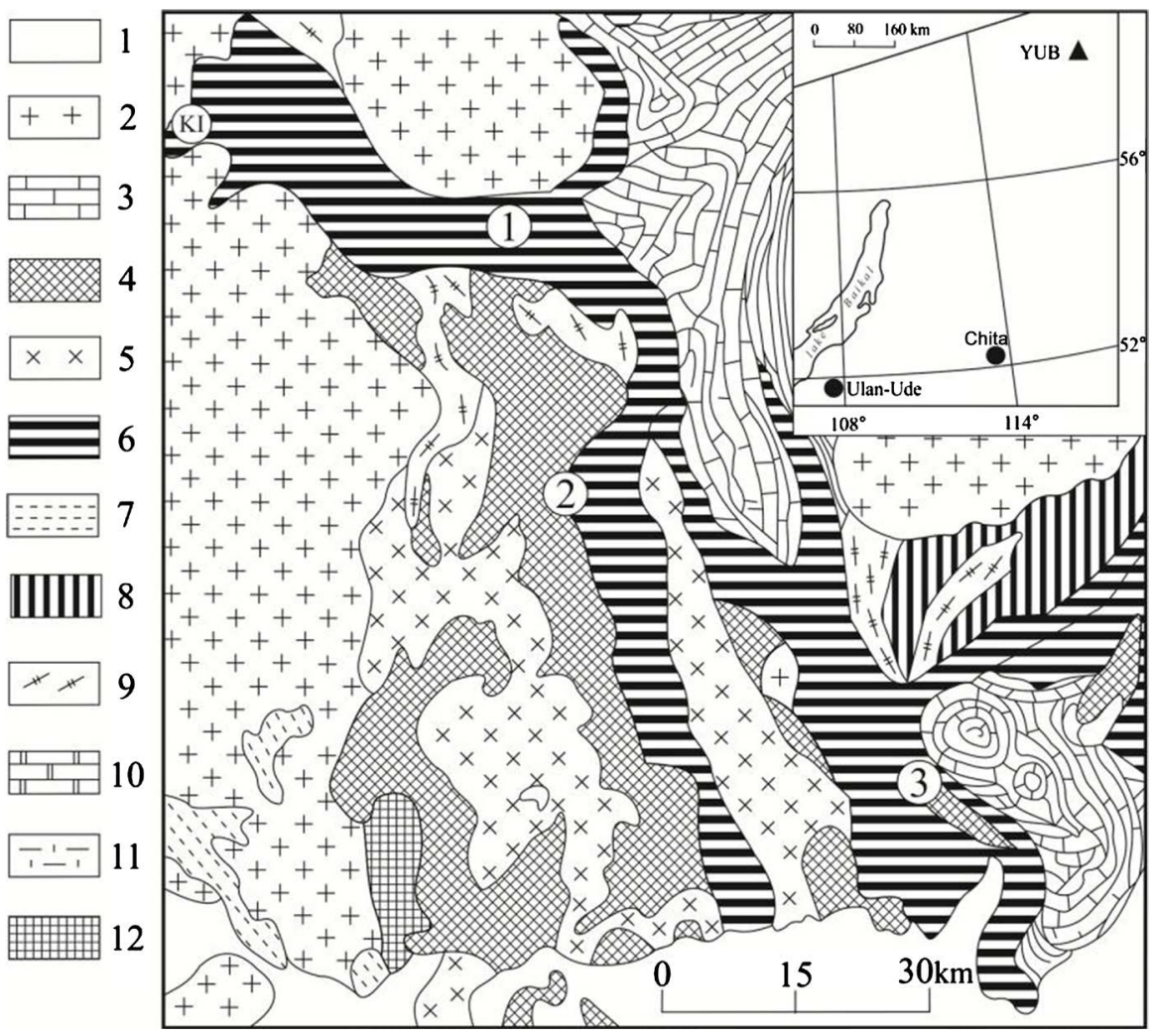

1-Cenozoic deposits; 2-granites of Paleozoic age; 3-Vendian-Cambrian carbonate formation; 4 - 5-Riphean massifs of Muya complex gabbro-diorite-granite association: 4-gabbroids, 5-diorites and plagiogranites; 6-Vendian-Riphean greenstone belts: KI -Kelyana-Irokinda; 7-Vendian-Riphean rocks of carbonate-black shale formation; 8-the same one of silicon-black shale formation; 9-diafluorinated pyroxenite-gabbro-amphibolite complex (the assumed fragment of the Paleoproterozoic greenstone belt); 10 - 12-the Muya microcontinent Precambrian rocks of the Siberian craton: 10-gneisses and crystalloslates, 11-marbles, 12-the calcareous crystalloslates, calciphyres. The numerals in circles mark ore fields (1-Yubileyny, 2-Irbo, 3-Kelyana). Mark YUB on the geographical scheme means Yubileyny field.

Figure 1. Mineragenic scheme of the Muya district South-Western part (materials of different years geological survey works are used). 
worked for less than a year. Its work had been stopped because of the low gold content in the ores, which could not ensure the profitability of underground mining. Thus, the results of all previously conducted exploration works did not allow to put on the balance of the significant gold reserves economically viable for underground mining (tunnel) method. Herewith, the possible use of the veined type deposits by open (quarry) method was not considered.

A.I. Zhilyaeva with co-authors [1] according to the probing analysis results also confirmed the non-industrial auriferousness, widely developed in the ore field, of beresitized and listwenitized rocks containing sulfide mineralization. Upon their data, the gold content in beresites is $1.5-2.8 \mathrm{~g} / \mathrm{t}$, and in listwenites is 0.1 - $1.5 \mathrm{~g} / \mathrm{t}$. Moreover, Au visible particles in the latter ones were not discovered. However, the verification sampling performed by the Buryatia Committee of Natural Resources, showed that content of $\mathrm{Au}$ in zones with quartz-sulphide veined-disseminated mineralization is commercial one $(\geq 4 \mathrm{~g} / \mathrm{t})$, but $\mathrm{Ag}$ varies in the range of $58.5-1549.3 \mathrm{~g} / \mathrm{t}$. The average amount of Au in beresitized rocks is $5.3 \mathrm{~g} / \mathrm{t}$. In listwenites zones (carbonatization, quartz-carbonate veining with pyrite, Galena, hematite, limonite) the $\mathrm{Au}(\mathrm{g} / \mathrm{t}) \mathrm{Au}$ concentration in single samples is $2 ; 15.7 ; 5.4$, and $\mathrm{Ag}-28.8 \mathrm{~g} / \mathrm{t}$.

Ambiguous $\mathrm{Au}$ and $\mathrm{Ag}$ contents characteristics complicate an objective assessment of the veined and disseminated mineralization productivity, the prospect perspectives of commercial deposits. Therefore, our research was focused on the study of lithological and petrographic control factors, material composition and productivity of various morphostructural types of ore mineralization in order to identify the distribution extent, except Au and Ag, of other useful components, the account of which could increase the value of extracted complex ores and thereby ensure the economic profitability of open-pit mining.

\section{Brief Structural and Geological Characteristics of the Ore Field}

Ore deposits of the Yubileyny field (Figure 1 ) is located on the Northern flank of Kelyana-Irokinda auriferous zone $(240 \times 25 \times 35 \mathrm{~km})$, previously allocated [2], as part of Bambuyka structural-metallogenic subzone, in its turn belonging to the Barguzin- Muya structural-metallogenic zone. Within Kelyana-Irokinda auriferous zone, which should be correctly called mineragenic, except auriferous objects in the rank of Yubileyny, Irbo and Irokinda deposits (located on the South-Eastern zone continuation), such mineral occurrence as Ikibzyak, Iligir, Bogodikan, Sosnovy site et al. and also Kelyana mercury deposit are known to be poorly studied. All of them, as shown in recent investigations [3] [4] [5], are located within the Vendian-Riphean Kelyana-Irokinda riftogenic greenstone belt, which was previously considered as one of the lower Proterozoic Baikal-Vitim greenstone belt branches due to the lack of isotopic dating [6]. The primary riftogenic Kelyana-Irokinda greenstone belt structure is overlaid by the regional charriage-shear zone (Figure 2), the formation of which was followed by dynamometamorphic 


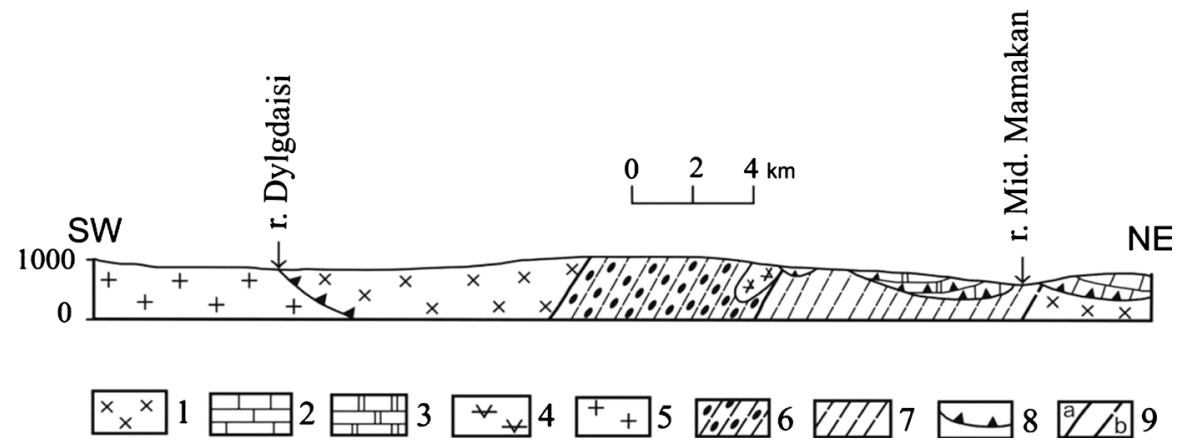

1-Muya complex gneisse granites and gabbroids; 2-lower Cambrian dolomite, limestone; 3-marls, and clay shales with interbedded limestone (middle Cambrian); 4-amphibolites on the picrite-komatiite-tholeiite series rocks of Kelyana-Irokinda greenstone belt; 5-Telmama complex Paleozoic granitoids; 6, 7-auriferous dynamometamorphic complex of the tectonic crush zone on the greenstone belt rocks: 6-identified boundaries of the Yubileyny auriferous field ore-bearing strata, 7-placer-forming auriferous strata, exposed in the form of clips, covered by the tectonic cover of the Cambrian carbonate rocks; 8-thrusts; 9-steep tectonic disturbances (a-identified, b-assumed).

Figure 2. The Yubileyny ore field position on the regional geological section.

transformations of the primary volcanic-plutonic association rocks and synchronous ore formation.

For the mentioned Kelyana-Irokinda greenstone belt auriferous objects (of the homonymous metallogenic zone) a spatial-genetic relation with dynamometamorphic complexes, formed on the picrite-komatiite-tholeiite series rocks (Table 1) is identified, including high silica magnesium boninite- like rocks group [4] [5], that is a characteristic feature of Archean greenstone belts [7]. The same volcano-plutonic series of high-magnesia rocks of the Vendian-Riphean age is proper to precious-metal deposits and occurrences localized in the neighboring Gukit-Parama greenstone belt and also, located further South, and more detailed studied, to Selenga-Vitim one [4]. Among the rocks of the productive dynamometamorphic complex on the Yubileyny ore field the massive fine-grained dark green amphibolites, plagioclase-amphibole rocks (tunnel 6) in the form of rare small relics (Table 1, samples YUB-90 and YUB-91) are met. They are composed by actinolite sheaf aggregates and plagioclase of the andesine-oligoclase series. Tremolite and aegirine were identified as secondary minerals. Accessory rutile and ilmenite were diagnosed. It is assumed that these rocks originated on the high-magnesia vulcanites. On the Northern flank of the ore field, geologists-surveyors identified hornblende amphibolites (Figure 3), the formation of which is associated with the metamorphism of the epidote-amphibolite facies, to which the Muya complex gabbroids were subjected. These are rocks composed of green hornblende, plagioclase (andesine-oligoclase); of secondary minerals, biotite, actinolite, rarely epidote are identified. The structure is granoblastic one, minerals arrangement is parallel-linear one, which say us abou their dynamometamorphic nature. From the accessory minerals, the ilmenite, sphene, rutile, magnetite, pyrrhotite, chalcopyrite were found. Perhaps the initial rock for the hornblende amphibolites formation was not the Muya complex gabbroids but pyroxenite komatiites like those that discovered on Irbo field [8], and earlier in 
Table 1. The magnesia metavolcanic rocks chemical composition of the Muya ore region Vendian-Riphean greenstone belts and the early Precambrian Olondo belt of Chara-Olyokma craton [4] [12] [13] [14].

\begin{tabular}{|c|c|c|c|c|c|c|c|c|c|c|c|c|}
\hline The rocks location & Sample numbers & $\mathrm{SiO}_{2}$ & $\mathrm{TiO}_{2}$ & $\mathrm{Al}_{2} \mathrm{O}_{3}$ & $\mathrm{Fe}_{2} \mathrm{O}_{3}$ & $\mathrm{FeO}$ & $\mathrm{MnO}$ & $\mathrm{MgO}$ & $\mathrm{CaO}$ & $\mathrm{Na}_{2} \mathrm{O}$ & $\mathrm{K}_{2} \mathrm{O}$ & $\mathrm{P}_{2} \mathrm{O}_{5}$ \\
\hline \multicolumn{13}{|c|}{ Vendian-Riphean Kelyana-Irokinda } \\
\hline \multirow[t]{2}{*}{ Irbo-Mladentsevsky ore zone } & M-78 & 48.13 & 0.63 & 8.02 & 1.85 & 8.67 & 0.18 & 23.93 & 8.30 & 0.29 & 0.05 & 0.05 \\
\hline & M-73 & 56.39 & 0.50 & 3.40 & 0.87 & 7.55 & 0.13 & 26.63 & 4.25 & 0.21 & 0.02 & 0.05 \\
\hline \multirow[t]{2}{*}{ Yubileyny ore field } & YUB-90 & 52.18 & 0.23 & 8.36 & 1.53 & 8.79 & 0.20 & 15.10 & 13.14 & 0.36 & 0.06 & 0.05 \\
\hline & YUB-91 & 47.65 & 0.30 & 13.48 & 3.21 & 10.09 & 0.23 & 11.22 & 13.07 & 0.60 & 0.15 & - \\
\hline \multicolumn{13}{|l|}{ Vendian-Riphean Gukit-Parama } \\
\hline \multirow[t]{3}{*}{ Samokut ore zone } & M-20 & 53.18 & 0.35 & 4.85 & 0.01 & 8.88 & 0.13 & 20.00 & 11.76 & 0.69 & 0.15 & - \\
\hline & M-19/1 & 52.24 & 0.18 & 4.52 & 1.94 & 7.63 & 0.22 & 19.59 & 12.67 & 0.47 & 0.49 & 0.05 \\
\hline & M-19/5 & 52.23 & 0.30 & 7.05 & 2.96 & 7.77 & 0.19 & 16.88 & 11.06 & 0.97 & 0.53 & 0.06 \\
\hline \multicolumn{13}{|l|}{ Early Precambrian Olondo } \\
\hline & & 48.02 & 0.39 & 7.12 & & $11.24^{*}$ & 0.20 & 25.68 & 6.89 & 0.18 & 0.03 & 0.03 \\
\hline & & 49.40 & 0.30 & 7.86 & & $10.11^{*}$ & 0.21 & 23.40 & 8.13 & 0.24 & 0.02 & 0.03 \\
\hline & & 48.71 & 0.45 & 8.83 & & $11.14^{*}$ & 0.28 & 22.06 & 7.69 & 0.44 & 0.03 & 0.05 \\
\hline & & 47.98 & 0.83 & 8.76 & & $13.69^{*}$ & 0.23 & 15.47 & 11.48 & 0.95 & 0.14 & 0.05 \\
\hline
\end{tabular}

M-Mladentsevsky, YUB-Yubileyny.

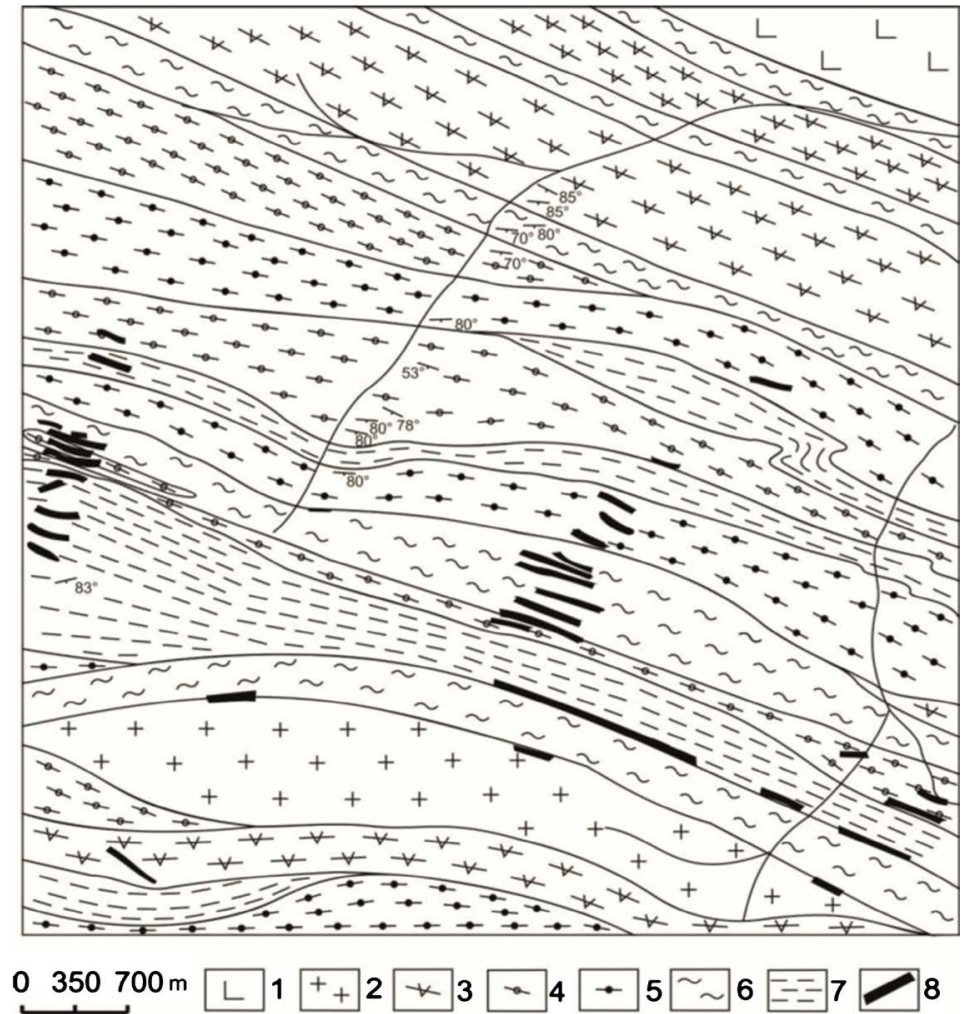

1-amphibolites (on pyroxenite komatiites?); 2-Muya complex cataclastic diorite, granodiorites, plagiogranites; 3-chlorite-plagioclase-amphibole mylonits on amphibolite; 4-Muscovite-quartz- plagioclase mylonites on granitoides of the Muya complex; 5-plagioclase mylonites on granitoides of the Muya complex; 6-7-expected ore zones (6-albite-quartz-sericite dynamoslates, 7-dynamoslates of chlorite-sericite-albite-quartz composition); 8- auriferous quartz veins.

Figure 3. Geological map of the Yubileyny ore field central part (used data [1] are given in our interpretation). 
Nyurundukan amphibolite strata of the North Baikal region [9]. On petrochemical diagram $\mathrm{MgO}-\mathrm{SiO}_{2}[10]$ the high-magnesia series metavulcanites enter the basalt komatiites field (sample YUB-90); and tholeiite basalts (sample YUB-91), and on the chart $\mathrm{Al}_{2} \mathrm{O}_{3} / \mathrm{TiO}_{2}-\mathrm{MgO}$ [11] they should be attributed respectively to the boninites and basalt komatiites. And the considered series rocks compositions of the Irbo-Mladentsevsky ore zone, where there is Irbo field, enter the komatiites and boninites petrochemical fields.

Note that the picrite-komatiite series of mesoarchean Olondo greenstone belt differ from the Vendian-Riphean belts by the absence of the boninites-like siliceous rocks group in its composition (Table 1). The structure of the crush zone steep-falling part in morphology and construction corresponds to the autoclastic lenticular-lamellar melange [15]. It marks the seam of a listric thrust. In this seam, the greenstone belt primary volcano plutonic rocks and the surrounding granitoids have been transformed into an ore-bearing dynamometamorphic complex.

\section{Material Composition Peculiar Properties of Dynamometamorphic Rocks}

As a result of tectonic-metamorphic changes in the primary rocks of the Vendian-Riphean age, up to the complete disappearance of the primary minerals and their primary structure, a dynamometamorphic complex was formed, represented by cataclasite, milonite and dynamoslate facies (Figure 3 ).

Cataclasites keep mineral composition and structures about $60 \%-80 \%$ of the initial rocks. The most common are the Muya complex cataclasites on diorites and granodiorites, which are disintegrated into sharp-angled fragments of different sizes. In the latter ones the areas with primary hypidiomorphic granular structure are being preserved. Considered cataclasite are heterogeneous in composition and construction. The partial recrystallization of finely splinted material is observed, the newly formed sericite, quartz, rarely ferrous carbonate are appeared.

A mylonite rocks characteristic peculiarity of chlorite-sericite-plagioclase, sericite-plagioclase, plagioclase-amphibole, chlorite-plagioclase compositions is the preservation of the relict fragments as the spectacle porphyroclasts surrounded by the sericite and chlorite linearly-laminated aggregates. The content of the latter ones reaches $10 \mathrm{wt} \%-15 \mathrm{wt} \%$. The plagioclase composition is mainly oligoclase one. In the rocks of blastomylonite variety-porphyroblastic process is manifested in the growth of cribriform prismatic albite, which replaces single oligoclase porphyroblasts. There are met also porphyroblasts of quartz, ferrous carbonate (ankerite, siderite) and pyrite. Apogranodiorite mylonites are composed by the fine-grained, fully recrystallized material of quartz-plagioclase or plagioclase-quartz composition, with sericite filamentary separations. The composition of the plagioclase is albite-oligoclase one. Quartz is scattered in the total rocks mass, there are also its lenticular-veined separations, the content of 
which reaches $40 \%$ - 45\%. Accessory minerals are represented by zircon, rutile, apatite, tourmaline (schorl), topaz. Rare scattered siderite and partly pyrite dissemination is observed.

Dynamoslate facies is represented by chlorite-Muscovite-albite-quartz, albite-quartz-Muscovite rocks. The dynamoslates appearance is associated with the development of late shift deformations and Kelyana-Irokinda shear zone formation in the final form. Dynamoslates compose the elongated bodies. In plan, they form a convergent and divergent band, delineating cataclasite and mylonites bodies. We can see a gradual transition of cataclasytized granites and porphyroclastic mylonites into dynamslates. For dynamoslates (attributed to them "beresites" and "listwenites") the typomorphic parageneses are chlorite + sericite + quartz + albite; sericite + albite + quartz.

The rocks texture is usually banded. The bands width is not seldom contiguous, reaches up to $15-20 \mathrm{~m}$. The structure is lepidogranoblastic one. Sericite is of two generations: 1) large-lamellar one associates with albite, coarsegrained veined quartz and chlorite; 2) small-lamellar one forms thin parallel bands. Chlorites are represented by ripidolite and pycnochlorites [1]. Carbonate of "beresites" and "listwenites" by composition refers to ferrodolomite and breunerite. According to our data, it crystallizes in the form of small $(0.1-0.5 \mathrm{~mm})$ porphyroblasts and aggregate clusters. Simultaneously with it, small veins of ore granular quartz are formed. On thin, parallel to foliation, cracks in dynamoslates the kaolinite in minor amounts develops. Dynamoslates are the vein comprising medium, the disseminated-veined zones with ore mineralization are concentrated in them too. Dynamoslates (ore-formational type of "mylonitization and foliation zones" by [16]) are feasible to regard as prospecting objects in auriferous zones.

Based on the data analysis presented in Table 2 and Table 3, the geochemical elements behavior and concentration peculiarities are revealed during the ore-hosting dynamometamorphic complex formation of the Yubileyny field. For dynamometamorphytes group formed on magmatic rocks of the picrite-komatiitetholeiite series:

1) at the early stage of deformational transformations at PT-conditions of the epidote-amphibolite facies (amphibolites) the most wide contents fluctuations are proper to $\mathrm{Cr}, \mathrm{Zn}$ and $\mathrm{Ba}, \mathrm{Sn}$ and $\mathrm{Nd}$, in less degree to $\mathrm{V}, \mathrm{Sb}, \mathrm{Sr}, \mathrm{Zr}, \mathrm{Y}, \mathrm{La}, \mathrm{Ce}$, $\mathrm{Pt}$ and Pd too;

2) late apoamphibolite dynamoslates, having lower concentrations levels $\mathrm{Cr}$, $\mathrm{V}, \mathrm{Y}, \mathrm{Pt}$ and $\mathrm{Pd}$ compared with the amphibolites are characterized by higher contents of $\mathrm{Co}, \mathrm{Pb}, \mathrm{Sn}, \mathrm{Sb}, \mathrm{Ba}, \mathrm{Sr}, \mathrm{Rb}, \mathrm{Ag}$ and especially $\mathrm{Au}$, with close values of $\mathrm{Zn}, \mathrm{Pb}, \mathrm{Zr}, \mathrm{Y}, \mathrm{Ce}, \mathrm{Nd}$.

Apodiorite mylonites, compared with the above-mentioned amphibolite, with wide concentrations fluctuations of $\mathrm{Cr}$ and $\mathrm{V}$ have lower their magnitudes. However, with a more contrast distribution of $\mathrm{Pb}, \mathrm{Sb}, \mathrm{Sr}, \mathrm{Rb}, \mathrm{Ce}, \mathrm{Nd}$, the maximum contents values of these elements reach larger values. They, being close in concentrations of $\mathrm{Ag}$ and $\mathrm{Au}$ with amphibolites, Pt and Pd are sharply depleted. 
Dynamoslates mainly inherit the contents levels of most mylonites microelements, except of $\mathrm{V}$ and Au higher values.

It should be noted that dynamoslates ore geochemical specialization (Table 2 ), which are the products of tectonic-metamorphic transformations of both basic and medium magmatic rocks, is very close. It is the result of the geochemical specificity inheritance of the primary volcano plutonic rocks pyrite-komatiitetholeiite series of Kelyana-Irokinda greenstone belt. Petrographic and mineralogical-geochemical signs of dynamometamorphic ore-hosting complex spatial-genetic relation with rocks of this series are as follows:

1) in dynamoslates, in the form of relics, amphibolites with basalts "shaddy" structure and preserved in the amphibole mass primary anortite are detected;

2) nickel, chrome and vanadium geochemical specialization is inherited by dynamometamorphytes, including ore quartz (Table 4). The presence of relic pentlandite and newly formed nickel-containing pyrite and pyrrhotite in the latter ones was identified (Table 5);

3) rutile, met in dynamometamorphytes, contains $\mathrm{V}$ to $0.92 \mathrm{wt} \%$ and the chlorite of the "beresites" and "listwenites " are enriched with $\mathrm{Cr}$ [1];

4) gold from quartz veins contains an admixture of Pt up to $0.13 \mathrm{wt} \%$ [1].

In the formation of Kelyana-Irokinda mineragenic zone tectonic structures three deformation stages [17] are allocated: 1) late Riphean thrust, 2) after the Cambrian thrusts and upthrows, 3) the Paleozoic left shear disturbances. Three time steps of dynamometamorphic (deformation-metamorphic) events should correspond them. Our research showed that Irbo deposit [8], jointed [1] with the

Table 2. Ore-hosting rocks geochemical characteristics of the Yubileyny ore field dynamometamorphic complex.

\begin{tabular}{|c|c|c|c|c|c|c|c|c|c|c|c|c|c|c|c|c|c|}
\hline $\begin{array}{c}\text { Sample } \\
\text { numbers }\end{array}$ & Rocks & $\mathrm{Cr}$ & $\mathrm{V}$ & Co & $\mathrm{Pb}$ & $\mathrm{Zn}$ & Sn & $\mathrm{Sb}$ & $\mathrm{Nb}$ & $\mathrm{Ba}$ & $\mathrm{Sr}$ & $\mathrm{Rb}$ & $\mathrm{Zr}$ & $\mathrm{Y}$ & $\mathrm{La}$ & $\mathrm{Ce}$ & $\mathrm{Nd}$ \\
\hline YUB-91 & Basalt metakomatiite & 54 & 310 & $<50$ & 19 & - & - & 4.3 & 6 & 280 & 190 & 72 & 210 & 53 & 30 & 64 & 23 \\
\hline YUB-90 & Metaboninite & 590 & 240 & $<50$ & 16 & 83 & 3.5 & 3.7 & 11 & 640 & 120 & 98 & 140 & 21 & 11 & 32 & - \\
\hline YUB-97 & Cataclasit on granodiorite & 49 & $<80$ & $<50$ & 170 & - & 3.2 & 7.3 & 11 & 450 & 57 & 150 & 200 & 35 & 22 & 55 & 22 \\
\hline YUB-6 & Milonit on diorite & 41 & $<80$ & $<50$ & 180 & - & 2.9 & 3.6 & 6 & 490 & 230 & 120 & 150 & 41 & 19 & 50 & - \\
\hline YUB-10 & --- “ --- “ --- & $<25$ & $<80$ & $<50$ & 21 & - & 2.1 & 2.4 & 7 & 540 & 180 & 84 & 120 & 30 & - & 26 & - \\
\hline YUB-16a & --- “ --- “ & 140 & 140 & $<50$ & - & - & - & - & 10 & 540 & 160 & 120 & 240 & 29 & 24 & 53 & 26 \\
\hline YUB-18 & --- “--- “--- & 180 & 140 & $<50$ & 72 & 63 & 4.6 & 23 & 17 & 880 & 101 & 170 & 285 & 48 & 46 & 92 & 48 \\
\hline YUB-15 & --- “ --- “ & 140 & 130 & $<50$ & 36 & 78 & 3.4 & - & 9 & 540 & 236 & 120 & 200 & 32 & 17 & 48 & - \\
\hline YUB-1 & Dynamoslate on amphibolite & 170 & 170 & 76 & 70 & 92 & 6.1 & 20 & 8 & 470 & 170 & 93 & 154 & 33 & 21 & 51 & 19 \\
\hline YUB-2 & --- “--- “ --- & 190 & 180 & 71 & - & - & 2.7 & 3.6 & 9 & 760 & 256 & 160 & 210 & 27 & 14 & 45 & - \\
\hline YUB-55 & Dynamoslate with talc addition & 140 & 140 & $<50$ & 22 & 65 & 2.8 & 3.5 & 12 & 640 & 130 & 140 & 160 & 28 & 24 & 57 & 25 \\
\hline $24-04 / 6$ & Dynamoslate on milonitized diorite & 130 & 140 & $<50$ & 77 & - & - & 11 & 12 & 380 & 170 & 176 & 200 & 37 & 12 & 36 & - \\
\hline YUB-44 & --- “ --- “ & 230 & 200 & $<50<$ & - & 43 & 2.5 & 3.3 & 11 & 670 & 79 & 136 & 250 & 36 & 28 & 68 & 20 \\
\hline YUB-67 & --- “ --- “ --- & 170 & 180 & 50 & 15 & 66 & - & 2.7 & 6 & 600 & 190 & 98 & 210 & 34 & 14 & 45 & - \\
\hline
\end{tabular}

Note: Ni content in samples YUB-90-2270 g/t, YUB-11 (dynamoslate on main high-mg volcanic rocks)—1870 g/t; "-”-not found. Analyses were performed in GIN SB RAS by B.Zh. Zhalsaraev (RFA-X-Ray Fluorescent Analysis). YUB-Yubileyny fied; GIN SB RAS-Geological Institute, Siberian Branch, Russian Academy of Sciences. 
Table 3. Noble metal contents in rocks of the ore-hosting dynamometamorphic complex according to the data of the atomic absorption analysis (analysts L. V. Mitrofanova and A. A. Tsyrenova, GIN SB RAS).

\begin{tabular}{|c|c|c|c|c|c|}
\hline Sample numbers & Rock & $\mathrm{Ag}$ & $\mathrm{Au}$ & $\mathrm{Pt}$ & $\mathrm{Pd}$ \\
\hline YUB-91 & Basalt metakomatiite & $1.0(0.30)$ & $10.0(27)$ & $4.0(412)$ & 32.0 \\
\hline YUB-90 & Metaboninite & $1.2(0.33)$ & $<10(0.23)$ & $9.0(72)$ & 17.5 \\
\hline YUB-97 & Cataclasyt on granodiorite & $<1.0$ & 10.0 & $<2$ & 0.2 \\
\hline YUB-6 & Milonit on diorite & 1.0 & $<10$ & $<2$ & $<0.2$ \\
\hline YUB-10 & --- “--- “--- & 1.0 & 15.0 & $<2$ & $<0.2$ \\
\hline YUB-16a & --- “ --- “ --- & 1.3 & $<10$ & $<2$ & 1.5 \\
\hline YUB-18 & --- “--- “--- & 1.3 & $<10$ & $<2$ & 1.0 \\
\hline YUB-15 & _ & 1.6 & $<10$ & $<2$ & 1.0 \\
\hline YUB-1 & Dynamoslate on amphibolite & 2.6 & 23.0 & $<2$ & 1.0 \\
\hline YUB-2 & --- “--- “--- & 1.3 & 47.0 & $<2$ & 1.0 \\
\hline YUB-55 & Dynamoslate with talc admixture & 2.2 & 83.0 & $<2$ & 1.5 \\
\hline $24-04 / 6$ & Dynamoslate on milonitized diorite & 1.2 & $<10$ & $<2$ & 1.0 \\
\hline YUB-44 & --- “--- “--- & 1.8 & 20.0 & $<2$ & 1.5 \\
\hline YUB-67 & --- “--- “--- & $<1.0$ & 13.0 & $<2$ & 1.5 \\
\hline
\end{tabular}

Note: $\mathrm{Ag}-\mathrm{g} / \mathrm{t}$; other elements-mg/t; in brackets-contents according to the microprobinng neutron- activation analysis (analyst G. M. Kolesov, Institute of Geochemistry, RAS). GIN SB RAS—Geological Institute, Siberian Branch, Russia Academy of Sciences. YUB-Yubileyny field

Table 4. V, Cr, Co (g/t) contents in ore quartz of Yubileyny field (quantitative spectral analysis, GIN SB RAS).

\begin{tabular}{ccccc}
\hline № & Sample number & Cr & V & Co \\
\hline 1 & $24-04 / 4$ & 240 & 210 & 79 \\
2 & YUB-88 & 75 & $<80$ & $<50$ \\
3 & YUB-92 & $<25$ & $<80$ & $<50$ \\
4 & YUB-100 & 28 & $<80$ & $<50$ \\
5 & YUB-101 & 120 & $<80$ & $<50$ \\
6 & YUB-105 & 120 & 85 & $<50$ \\
7 & YUB-108 & 220 & 210 & $<50$ \\
\hline
\end{tabular}

Table 5. Amphiboles chemical composition (vol\%).

\begin{tabular}{|c|c|c|c|c|c|c|c|c|c|}
\hline \multirow{2}{*}{$\begin{array}{c}\text { The elements oxides } \\
\qquad \mathrm{SiO}_{2}\end{array}$} & \multicolumn{5}{|c|}{ The ore-bearing dynamoslates of Yubileyny field } & \multicolumn{4}{|c|}{ Olondo greenstone belt metakomatiites [12] } \\
\hline & 52.89 & 49.78 & 52.28 & 51.83 & 51.03 & 49.28 & 47.90 & 52.1 & 51.32 \\
\hline $\mathrm{TiO}_{2}$ & - & 0.42 & - & - & 0.49 & 0.276 & 0.274 & 0.218 & 0.148 \\
\hline $\mathrm{Al}_{2} \mathrm{O}_{3}$ & 3.97 & 7.49 & 5.52 & 6.20 & 8.00 & 8.89 & 9.75 & 6.88 & 7.35 \\
\hline $\mathrm{Cr}_{2} \mathrm{O}_{3}$ & 0.46 & 0.47 & 0.49 & 0.40 & - & 0.366 & 0.383 & 0.308 & 0.376 \\
\hline $\mathrm{FeO}$ & 11.32 & 12.83 & 11.45 & 11.85 & 13.32 & 9.32 & 9.80 & 10.51 & 9.17 \\
\hline $\mathrm{MgO}$ & 16.29 & 14.42 & 15.99 & 15.28 & 14.86 & 16.47 & 15.53 & 18.13 & 17.18 \\
\hline $\mathrm{CaO}$ & 12.60 & 12.73 & 12.76 & 13.04 & 13.16 & 11.85 & 11.90 & 9.04 & 11.97 \\
\hline $\mathrm{MnO}$ & - & - & - & - & - & 0.143 & 0.121 & 0.222 & 0.143 \\
\hline $\mathrm{Na}_{2} \mathrm{O}$ & - & 0.61 & 0.49 & - & - & 1.13 & 1.23 & 0.837 & 0.836 \\
\hline
\end{tabular}

The analyses were performed on the electron microscope LEO-1430VP by N.C. Karmanov. 
Yubileyny field into a single Irbo-Yubileyny ore field, its ore-forming dynamometamorphic complex is really formed in three steps (Rb-Sr Dating): the Cambrian, Devonian and Carboniferous. The Riphean age characterizes the early ore preparative magmatic stage of the Kelyana-Irokinda mineragenic zone ore-forming system. Analogically with Irbo field, we can assume a three-step dynamometamorphysm in the Yubileyny ore field too, in the sequence: amphibolites-cataclasites, mylonites-dynamoslates, ore vein quartz [8].

\section{Morphostructural Mineralization Types and Ores Material Composition}

Ore mineralization is localized in the veins of granular in different degrees quartz, in the zones of quartz and quartz-carbonate veining, sulfidization.

All of them are mainly located in the contours of dynamoslates ore zones of the albite-quartz-Muscovite composition (see Figure 3). Not-auriferous or weakly auriferous quartz veins are commonly characteristic for cataclasites. According to exploration works, the quartz veins are characterized by tabular form, complicated with bends and crimps, perform plane dynamometamorphic bending and cleavage cracks. The quartz is milky white with transitions to gray blocky, sectionally mainly (by cracks) granular.

The ore quartz veins often disintegrate into a number of lenses or pass in thin veinlets as it is proper to auriferous quartz veins of the stem type, localized in the mylonites (Irbo ore field).

Linear zones of quartz veining with a thickness of 1.5 - 8 m contain from $10 \%$ - $20 \%$ to $30 \%-40 \%$ of veinlets. The number of such zones that it is advisable to allocate as a potential ore deposits, reaches $10-12 \mathrm{~m}$ while the dynamoslates zones width comprising them is from 200 to $500 \mathrm{~m}$. Sulfide-quartz-carbonate veining zones possess a wider variation of the visible thickness $(0.2-2 \mathrm{~m} 10-30$ $\mathrm{m})$. Their length reaches $200 \mathrm{~m}$. Previously estimated $\mathrm{Au} \mathrm{P}_{2}+\mathrm{P}_{3}$ reserves on these areas the resources, were in the amount of 26.4 tons.

Quartz-vein type is characterized by poor-sulfide (up to $1 \%$ of sulfides), quartz and sulfide-quartz technological ores varieties. For veining zones, the same technological ore groups with mineral subtypes: gold polymetallic one with faded ores, gold-polymetallic one with boulangerite and hessite, gold-polymetallic one with arsenopyrite, boulangerite and faded ores, gold-polymetallic one with scheelite and faded ores.

About 100 ore minerals are known in quartz veins and veinlets. The most common among them are sulfides, in less degree sulphosalts of heavy metals. The rare met tellurides and native metals are very deverse (Table 6). Mineral paragenetic associations of ore quartz veins are represented by (from early to late one): quartz, quartz-pyrite, quartz-sphalerite-chalcopyrite-Galena and gold-telluride-quartz one.

Ore mineralization of sulfide disseminated zones is mainly represented by pyrite, but pyrrhotite, chalcopyrite, sphalerite, Galena, magnetite, marcasite, rutile, native gold there are in subordinate amounts. 
Pyrite forms cubic shape grains, uniformly distributed throughout the rock and rarely met in the form of pentagonal-dodecahedrons. Grain sizes vary from $0.01-0.05$ to $0.08-2 \mathrm{~mm}$. Pyrite small grains form not seldom aggregates of irregular shape $(0.8-4 \mathrm{~mm})$ and elongated separations $(0.5-3 \mathrm{~mm})$, sometimes located together with kaolinite along thin cracks. Pyrite grains are fractured, contain many different ore inclusions (pyrrhotite, rutile, chalcopyrite, magnetite, pentlandite, sphalerite). Iron hydroxides develop throughout the pyrite. Pyrite not seldom associates with carbonate, quartz-carbonate veinlets too. Gold in pyrite is in a fine state. Its content is $3-15 \mathrm{~g} / \mathrm{t}$ (Table 7).

Pyrrhotite is concentrated in the chlorite and micaceous mass, forming grains, unevenly distributed in the rock. Their shape is laminated, isometric, elongated, rarely irregular, from $0.05-0.15 \mathrm{~m}$ to $0.2-0.3 \mathrm{~mm}$. It everywhere is replaced by pyrite and occurs in close accretion with chalcopyrite.

Chalcopyrite is marked in the form of separate, irregular-shaped grains of 0.05 $-0.1 \mathrm{~mm}$ in size and in accretions with pyrrhotite, pyrite. It also associates with magnetite and rutile. Single grains are not rare in micaceous-carbonate mass.

Pyrrhotite is concentrated in the chlorite and micaceous mass, forming grains, unevenly distributed in the rock. Their shape is laminated, isometric, elongated, rarely irregular, from $0.05-0.15 \mathrm{~m}$ to $0.2-0.3 \mathrm{~mm}$. It everywhere is replaced by pyrite and occurs in close accretion with chalcopyrite.

Table 6. Ores mineral composition of the Yubileyny field (partly used information [1]).

\begin{tabular}{|c|c|c|}
\hline $\begin{array}{l}\text { Morphostructural } \\
\text { mineralization type }\end{array}$ & Main ore minerals & Typical secondary and accessory ore minerals \\
\hline Veinlet-veined & $\begin{array}{c}\text { Pyrite, Galena, sphalerite, } \\
\text { chalcopyrite }\end{array}$ & $\begin{array}{l}\text { Native } \mathrm{Au}, \mathrm{Ag}, \mathrm{Cu}, \mathrm{Bi}, \mathrm{Sb}, \mathrm{Te}, \mathrm{Pt} \text { ?, } \mathrm{Pd} \text { ?, } \mathrm{Ru}(\mathrm{Os}, \mathrm{Jr}) \text {, altait- } \mathrm{PbTe} \text {, petzite- } \mathrm{Ag}_{3} \mathrm{AuTe}_{2} \text {, } \\
\left.\text { hessite- } \mathrm{Ag}_{2} \mathrm{Te} \text {, calaverite- } \mathrm{AuTe} \mathrm{e}_{2} \text {, coloradoite- } \mathrm{HgTe} \text {, krennerich- } \mathrm{Au}, \mathrm{Ag}\right) \mathrm{Te}_{2} \text {, } \\
\text { Silvana- } \mathrm{AgAuTe}_{4} \text {, tellurobismuthite- } \mathrm{Bi}_{2} \mathrm{Te}_{3} \text {, impressit- } \mathrm{AgTe} \text {, vulcanite- } \mathrm{CuTe} \text {, } \\
\text { Riccardi- } \mathrm{Cu}_{3} \mathrm{Te}_{2} \text {, melonit- }-\mathrm{NiTe}_{2} \text {, clausthalite-PbSe, umangite- }-\mathrm{Cu}_{3} \mathrm{Se}_{2} \text {, magnetite, hematite, } \\
\text { hubnerite, ilmenite, rutile, tetrahedrite, tetradymite, marcasite, molybdenite, pentlandite, } \\
\text { pyrrhotite, nagyagite- } \mathrm{Pb}_{5} \mathrm{Au}(\mathrm{Te}, \mathrm{Sb})_{4} \mathrm{~S}_{5-8} \text {, arsenopyrite }\end{array}$ \\
\hline Disseminated & Pyrite & $\begin{array}{l}\text { Pentlandite, pyrrhotite, chalcopyrite, sphalerite, Galena, marcasite, ilmenite, magnetite, } \\
\text { hematite, rutile, native } \mathrm{Au}, \mathrm{Ag}, \mathrm{Fe}, \mathrm{Pt} \text { ?, } \mathrm{Ru}(\mathrm{Os}, \mathrm{Jr}), \mathrm{Pd} \text { ? }\end{array}$ \\
\hline
\end{tabular}

Table 7. Gold content (g/t) in pyrites from different morphostructural types of mineralization (atomic absorption, analyst M. G. Egorova, GIN SB RAS).

\begin{tabular}{ccc}
\hline Sample numbers & $\mathrm{Au}$ & Morphostructural mineralization type \\
\hline $24-04$ & $>500$ & Quartz-vein \\
YUB-84 & $>500$ & --- " --- " --- \\
YUB-101 & 50 & --- " --- " --- \\
$24-04 / 2$ & 15 & --- " --- " --- \\
YUB-57 & 70 & Veined-quartz in dynamoslates \\
$24-04 / 5$ & 3.0 & Disseminated in dynamoslates \\
YUB-47 & 15 & --- " -- " --- \\
& & \\
\hline
\end{tabular}

GIN SB RAS—Geological Institute, Siberian Branch, Russian Academy of Sciences. YUB—Yubileyny field. 
Chalcopyrite is marked in the form of separate, irregular-shaped grains of 0.05 $-0.1 \mathrm{~mm}$ in size and in accretions with pyrrhotite, pyrite. It also associates with magnetite and rutile. Single grains are not rare in micaceous-carbonate mass.

Magnetite is met as small inclusions $(0.08-0.1 \mathrm{~mm})$ of isometric form with uneven contours, sometimes forming cubic crystals $(0.08-0.12 \mathrm{~mm})$. It is in close association with chlorite, chalcopyrite. There are admixtures of Ti up to $2.96 \%$.

Marcasite is crystallized into lenticular form aggregates $(0.1-0.3 \mathrm{~mm})$, closely associates with carbonate, that give an evidence of their simultaneous formation.

Pentlandite grains were found in pyrite. Their form is isometric, sizes are up to $0.1 \mathrm{~mm}$.

Rutile of prismatic and needle forms is met as separate grains of the irregular form. It associates with mica, pyrite, tourmaline, hematite. As the admixtures elements, $\mathrm{Fe}$ ( $\mathrm{FeO}$ up to $1.31 \%$ ) and $\mathrm{V}\left(\mathrm{V}_{2} \mathrm{O}_{5}\right.$ up to $\left.1.35 \%\right)$ are identified in it.

Central low-sulphide zones of ore quartz veins carry predominantly $\mathrm{Au}-\mathrm{Ag}-\mathrm{Pt}$ mineralization, and their sulfide rims are enriched with $\mathrm{Ru}, \mathrm{Jr}, \mathrm{Os}, \mathrm{Cu}, \mathrm{Zn}, \mathrm{Pb}$, $\mathrm{Sb}$, that allows us to consider them as clusters with multicomponent noble metal-polymetallic ores (Table 8). Looking at the concentrations ratio of $\mathrm{Os,} \mathrm{Jr}, \mathrm{Ru}$

Table 8. The main ore elements content in different types of mineralization. Determine methods: $\mathrm{Ni}, \mathrm{Cu}, \mathrm{Zn}, \mathrm{Pb}, \mathrm{Sb}-\mathrm{RFA}$ (B. J. Zhalsaraev, GIN SB RAS), Pd-atomic absorption (M. G. Egorova, GIN SB RAS), Ag, Au, and PGE-microprobing neutron activation analysis (G. M. Kolesov, Institute of Geochemistry, RAS).

\begin{tabular}{|c|c|c|c|c|c|c|c|c|c|c|c|c|}
\hline Sample numbers & $\mathrm{Ni}$ & $\mathrm{Cu}$ & $\mathrm{Zn}$ & $\mathrm{Pb}$ & $\mathrm{Sb}$ & $\mathrm{Ag}$ & $\mathrm{Au}$ & $\mathrm{Pt}$ & $\mathrm{Pd}$ & Os & $\mathrm{Jr}$ & $\mathrm{Ru}$ \\
\hline \multicolumn{13}{|l|}{ Quartz-vein type } \\
\hline 24-04 & 0.0003 & 1.91 & 2.19 & 2.28 & 11.0 & 454.7 & 35.9 & - & $<0.2$ & n.d & n.d & n.d \\
\hline YUB- $84^{*}$ & 0.0004 & 1.56 & 1.51 & 1.90 & 9.5 & 254.6 & 120.0 & - & 0.2 & 5890 & 7800 & 146000 \\
\hline YUB-101 & n.d & 0.156 & - & 0.061 & 0.004 & 8.44 & 4.8 & 4.56 & 2.0 & - & 0.58 & 30.3 \\
\hline $24-04 / 1$ & 0.0003 & 0.123 & 0.051 & 0.183 & 0.410 & 26.0 & 13.2 & - & 0.2 & n.d & n.d & n.d \\
\hline YUB-108 & n.d & 0.533 & 0.957 & 0.521 & 0.047 & 80.0 & $>1.0$ & - & 2.0 & n.d & d.n & n.d \\
\hline YUB-88 & n.d & 0.040 & 0.012 & 0.026 & 0.190 & 14.2 & $>1.0$ & - & 1.0 & n.d & n.d & n.d \\
\hline $24-04 / 2$ & 0.0010 & 0.022 & 0.018 & 0.038 & 0.130 & 6.2 & 0.9 & - & 1.0 & n.d & n.d & n.d \\
\hline \multicolumn{13}{|c|}{ Disseminated sulfide type } \\
\hline YUB-47 & 0.228 & 0.086 & - & 0.077 & 0.001 & 20.0 & 0.316 & n.d & n.d & n.d & n.d & n.d \\
\hline YUB-55 & n.d & n.d & n.d & n.d & n.d & 27.6 & 1.36 & 0.196 & 1.5 & 1.84 & 1.31 & 16.6 \\
\hline YUB-44 & n.d & n.d & n.d & n.d & - & 0.21 & 0.0477 & 0.460 & 1.5 & 1.71 & 0.73 & 12.5 \\
\hline YUB-102 & n.d & - & 0.0063 & 0.0072 & - & 0.72 & 0.109 & 0.668 & - & 1.68 & 2.02 & 17.4 \\
\hline YUB-50 & 0.074 & - & 0.0084 & 0.0076 & 0.0068 & 2.8 & 0.038 & - & 1.0 & n.d & n.d & n.d \\
\hline YUB-9 & 0.227 & 0.006 & 0.0051 & - & - & n.d & n.d & n.d & n.d & n.d & n.d & n.d \\
\hline YUB-13 & 0.069 & 0.016 & 0.0063 & 0.0025 & - & 1.2 & n.d & - & 1.0 & n.d & n.d & n.d \\
\hline YUB-11 & 0.187 & - & 0.0037 & - & 0.00035 & n.d & n.d & n.d & n.d & n.d & n.d & n.d \\
\hline
\end{tabular}

Note. Concentrations of: $\mathrm{Ni}, \mathrm{Cu}, \mathrm{Zn}, \mathrm{Pb}$ and $\mathrm{Sb}$-in wt\%; Ag, Au and Pt—in g/t, other elements—in mg/t; n.d-content was not determined, “_”-not found, *-vein sulfide rim 70. YUB-Yubileyny field. GIN SB RAS-Geological Institute, Siberian Branch, Russian Academy of Sciences. 
in sulfide rims, the most possible presence form of these platinoids is as native ruthenium with an admixture of Os and Jr. Mineralogical analysis of the YUB-84 (vein 70) sample sulfide graviconcentrate showed the following ore minerals species composition: sphalerite (34\%), faded ore (30\%), Galena (21\%), pyrite (15\%), chalcopyrite (rare signs). Zn contents in quartz veins reaches $3.6 \mathrm{wt} \%, \mathrm{~Pb}$ to $8.1 \mathrm{wt} \%, \mathrm{Sb}$ up to $11 \mathrm{wt} \%$. Disseminated sulfide zones contain significantly less of $\mathrm{Au}, \mathrm{Ag}$, platinoids (up to $0.69 \mathrm{~g} / \mathrm{t}$ ), polymetals, but are enriched with $\mathrm{Ni}$ due to the presence of pentlandite, nickel-containing pyrite and pyrrhotite. They can be considered as the complex nickel-noble metal ores.

\section{Mylonite and Dynamoslate Mineralized Zones-Perspective Prospect Objects of Polycomponent Ores Large Capacity Deposits}

Within the Yubileyny ore field central part, studied by mining and drilling works, the authors have allocated 8 mineralized ore zones with a visible thickness on the surface of $150-700 \mathrm{~m}$, the extent length of which is not identified, since they have not been monitored beyond the boundaries of the presented map (Figure 3). In these zones the most part of the revealed by present time ore quartz veins of veinlet occurrence and disseminated mineralization type are localized. The set of these morphostructural mineralization types determine the ore-bearing zones high potential for large-capacity ore deposits prospecting of multicomponent composition, in which the noble metals ( $\mathrm{Au}, \mathrm{Ag}$ and $\mathrm{EPG}$ ) take place of leading position, and polymetals $(\mathrm{Cu}, \mathrm{Pb}, \mathrm{Zn}), \mathrm{Ni}, \mathrm{Co}, \mathrm{Sb}, \mathrm{Zr}$ have secondary industrial value (minor components). It is known that large-capacity deposits are characterized by significantly lower industrial contents of ore components, compared with ordinary ones, by the dominance of veined-disseminated and disseminated mineralization types, as well as by capacity parameters that allow them to operate in an open (quarry) way. Zones of disseminated sulfide mineralization are especially relevant for the prospecting, which are not only characteristic to the Yubileyny ore field, but are also widely represented in other parts of the Kelyana-Irokinda zone [18]—Kelyana riverhead $(8 \times 3.5 \mathrm{~km})$ and Irokinda deposit area ( 8 areas with a total area of $24 \mathrm{~km}^{2}$ ). We emphasize the fact that at least some of the most explored quartz veins enriched by noble metals enter the quarry developments contours.

\section{Recommended Approaches, Productivity Investigation Methods of Ore Mineralization due to the Revaluation of the Yubileyny Ore Field Industrial Prospects, Other Transbaikalia Noble-Metal Objects}

Most part of the industrial auriferous deposits in the Northern and Western Transbaikalia areas (Buryatia) were revealed, evaluated and explored in the 50 80 years of the XX century. The works were mainly focused on expect-prospecting for vein gold-quartz and gold-sulfide-quartz mineralization types. At the same 
time, the evaluation, deposits exploration regardless of the gold coarseness and its distribution nature, was carried out by a single method of trenching sampling. These approaches have largely survived to this day. However, the vein type of industrial mineralization potential was almost exhausted, and attempts of ore bodies prospecting and assessment with veined-disseminated gold-sulfide-quartz and disseminated gold-sulfide mineralization types, which are associated worldwide with large-capacity reserves and relatively poor in content $(2-4 \mathrm{~g} / \mathrm{t})$ deposits, were mostly ineffective due to the trenching sampling application as the main method of ore bodies delineation, of reserves evaluation.

Due to the insufficient effectiveness of traditional trenching sampling method in the prospects, evaluation and exploration of ore bodies with large ash nugget and extremely non-uniform its distribution, many of the Kelyana-Irokinda objects have been undervalued and even discredited as perspective ones (Yubileyny, Irbo, Irokinda ore fields; occurrences-Samokut, Osinovy, Upper-Samokut and others, Selenga-Vitim (Tsipikan, Gorbilok ore zones) greenstone belts of the Vendian-Riphean age [19].

Ignored and not studied a large group of ore fields tectonic structures complex in the construction, ore zones such as "zone of tectonic and autoclastic mélange with their varieties: coarse-block, middle-block, small-block, lenticular-laminated", "losange zones (duplex) of different extent", "zones of multi-seam, low amplitude thrusts" that are widespread in many auriferous areas of Transbaikalia [19].

The above mentioned types of charriage-thrust structures are proper to a new formartional type of gold mineralization allocated by A. D. Shcheglov, which he called "zones of mylonitization and foliation" [16] and confined with dynamometamorphic complexes-dynamo-genic by the deposits Genesis [20].

When studying the Yubileyny field ore zones productivity, it is necessary not to use trenching sampling as the main ore zones evaluation method, replacing it by small-capacity bulk sampling, with the following results certification with single large-capacity bulk samples.

We recommend to reevaluate the Yubileyny ore field industrial (commercial) prospects, changing a strategy, prospecting technique and ore bodies evaluation. There are all prerequisites for the detection of multicomponent ores large-tonnage deposits, cost-effective for an open pit mining.

The most important problem is the available forms detection of "invisible" PEG and partially Au. Perhaps a significant part of this difficulty to enrich variety of ore mineralization is represented by fine nanominerals, cluster, colloidal forms, which require the development of new technological enrichment schemes, different from traditional ones.

\section{Conclusions}

Yubileyny ore field considered as example in the article allows us to offer some relevant measures to improve the economic efficiency of the mining industry in Buryatia, namely: 
1) To change the strategy of predictive-metallogenic, expect-prospecting and exploration works for gold with a focus on the identification of large reserves ( $\geq 100$ tonnes), suitable for open pit mining with polycomponent ores localized in the Vendian-Riphean greenstone belts and confined with dynamometamorphic complexes developing on the rocks of the picrite-komatiite-tholeiite series. To date, according to our preliminary estimates, in addition to the Yubileyny field, the primary objects of the prospecting stage, reserves of which are determined (up to depth of quarry development-50 m) at least of $150-200 \mathrm{t}$ for each one, are: Lower Samokut and Tsipikan zones;

2) When carrying out expect-prospecting and prospect-evaluating work it is necessary to use a cheap express mapping mineral-geochemical method of productive zones and bodies [21];

3) To put in practice of expect-prospecting and exploration work the more reliable bulk sampling method instead of ineffective trenching sampling. To study large-capacity bulk ore samples, it is necessary to have a special small enrichment factory on the territory of Buryatia, the corresponding modular units, to use the methodological developments of TsNIGRI, Magadan, Chita and Irkutsk geologists.

\section{Conflicts of Interest}

The authors declare no conflicts of interest regarding the publication of this paper.

\section{References}

[1] Zhilyaeva, I.A., Naumov, V.B. and Kudryavtseva, G.P. (2000) Mineral Composition and Formation Fluid Regime of Yubileyny Auriferous Deposit (Transbaikalia, Russia). Geology of Ore Deposits, 42, 63-73.

[2] Buryatia Gold (2004) Book 1, BNTs SB RAS, Ulan-Ude.

[3] Mineeva, I.G. and Arkhangel'skiy, V.V. (2007) A New Direction in Methodology of Uranium and Gold Uranium Deposits Identification in Shields and the Precambrian Folded Regions. Prospecting and Protection of Bowels, 11, 18-25.

[4] Tatarinov, A.V., Yalovik, L.I. and Batyshev, V.G. (2014) Noble-Metal Ore-Forming System of the Vendian-Riphean, Selenga-Vitim Greenstone Belt. Domestic Geology, 3, 17-25.

[5] Tatarinov, A.V., Yalovik, L.I. and Vanin, V.A. (2016) Spherical Microparticles of the Irokinda Deposit Gold Quartz Veins (Western Transbaikalia). Geodynamics and Tectonophysics, 7, 651-662. https://doi.org/10.5800/GT-2016-7-4-0226

[6] Fedorovsky, V.S. (1985) Lower Proterozoic of Baikal Mountain Region. Science, Moscow.

[7] Bogatikov, O.A., Kovalenko, V.I. and Sharkov, E.V. (2010) Magmatism, Tectonics, Geodynamics of the Earth: Connection in Time and in Space. Science, Moscow.

[8] Tatarinov, A.V., Yalovik, L.I. and Posokhov, V.F. (2014) Formation Peculiarities of Irbo Deposits Precious Metals (Western Transbaikalia). Geology and Mineral Resources of Siberia, 3, 117-119.

[9] Konnikov, E.G. and Tsygankov, A.A. (1997) Orthopyroxenite with the "Spinifex" 
Type Structure from Nyurundukan Suite of Northern Baikal. Russian Academy of Sciences Proceedings, 356, 226-229.

[10] Frolova, T.I. and Kotorgin, N.F. (1986) To the Problem of Picrites and Komatiites Classification. Bulletin of Moscow University, Geology, 4, 3-17.

[11] Kulikov, V.S. and Kulikova, V.V. (2000) A New Approach to the Classification of High-Magnesium Rocks. The Second Russian Petrographic Meeting, 1, 111-112.

[12] Popov, N.V., Smelov, A.P. and Dobretsov, N.L. (1990) Olondino Greenstone Belt. YANTS SB USSR, Yakutsk.

[13] Tatarinov, A.V. and Yalovik, L.I. (2003) Material Composition Particularities of Rocks and Schlich-Mineralogical Complexes of Olondino Greenstone Belt. BNTS SB RAS, Ulan-Ude.

[14] Yalovik, L.I., Tatarinov, A.V., Mironov, A.G., et al. (2006) First Rocks Findings of the Komatiite Series in the Muya Auriferous Area. Volcanism and Geodynamics, Buryatia.

[15] Tatarinov, A.V. and Yalovik, L.I. (2006) Dynamometamorphysm Is the Main Formation Factor of Collisional Gold Deposits. Auriferous Deposits in East of Russia, 32-49.

[16] Shcheglov, A.D. (1997) About a New Type of Gold Deposits and Prospects of Their Discovery. Exploration and Protection of Mineral Resources, 11, 10-11.

[17] Korol'kov, A.T. (2007) Auriferous Regions Geodynamics of the East Siberia South. Publishing House of Irkutsk State University, Irkutsk.

[18] Abramov, B.N. (2006) Gold-Quartz Formation Deposits Conditions in the Muya Zone (Northern Transbaikalia). Reports of Academy of Sciences, 410, 643-646.

[19] Tatarinov, A.V., Yalovik, L.I. and Yalovik, G.A. (2006) About the Direction of Prospecting and Exploration Works for Gold of Buryatia. Status and Development Analysis of the Baikal Nature Territory: The Mineral-Raw Material Complex, Buryatia.

[20] Shcheglov, A.D. (2007) The Main Problems of Metallogeny. Selected Works. St. Petersburg.

[21] Tatarinov, A.V., Yalovik, G.A. and Yalovik, L.I. (2011) Non-Traditional Methods of Local Expection, of Gold Mineralization Productivity Estimation in Carbonaceous Complexes of Kular-Nersk Shale Belt. Ores and Metals, 5, 43-51. 